\title{
Research on Impact of the Learning Environment Created With Theory of Multiple Intelligences on Student Success
}

\author{
Hamza AKENGIN \\ Marmara University, Istanbul, Turkey \\ Yasemin YABANSU \\ Kuleli Secondary School, Istanbul, Turkey
}

\begin{abstract}
This research aims to determine the feasibility of Theory of Multiple Intelligences, a theory that regards individual differences among students and suggests organization of education environment, so as to address different intelligence modalities in teaching social sciences and to reveal the impact of this theory on improving the conduct of students towards social sciences classes. For the research, the chapter titled "Resources of Our Country" has been selected among the 6th grade social sciences chapters. The aim is to determine the contribution of Theory of Multiple Intelligences to the success of the students and memorability of the information contained therein. Research has been conducted for 6 weeks among the 6th grade students of İstanbul Bahçelievler Kuleli Middle School in the first semester of academic year 2014-2015. The research utilizes pretest-posttest design with the control group. Two classes of the 6th graders of the school has been selected impartially. While the courses were performed according to constructivist approach in the control group, the courses in the experimental group were conducted with activities constructed according to Theory of Multiple Intelligences. The sample of the research consisted of 36 students in the experimental group and 33 students in the control group. Achievement test prepared by the researches has been applied to students for gathering data. Results are evaluated with Man-Whitney $U$ Test.

Keywords: Theory of Multiple Intelligences, social sciences education, resources of or country.
\end{abstract}

\section{Introduction}

Education aims to establish several behavioral changes in cognitive, affective, and kinetic areas in individuals or to develop new behavior. Although schools have a common goal in this respect, it should be noted that students reach the classroom environment from different background and experiences. They all have different areas of interest, learning methods, strengths, and weaknesses. Therefore, education process should be designed to address these differences. According to Gardner (2010), there is no single teaching method and all children do not learn the same.

Theory of Multiple Intelligences acknowledges that all children cannot learn with the same method. The underlying reason is the individual differences between children. Each student has a dominant intelligence in unique areas. Therefore, a course should be taught using as many different techniques and methods as possible. Course contents prepared, according to Theory of Multiple Intelligences, can become an efficient tool in this

Hamza AKENGIN, Dr., associate professor, Department of Geography, Faculty of Arts and Sciences, Marmara Unıversity. Yasemin YABANSU, M.A. of Social Studies Education, Social Studies Teacher in Kuleli Secondary School, Istanbul, Turkey. 
respect. Theory asserts applying different activities with regards to differences between the students and classifies students as less talented/more talented" instead of "hard working" or "lazy" (Kabapınar, 2012). It is safe to assume that a student not influenced under two poles and not labeled as on or other will feel happier and more peaceful in the classroom environment, will have higher confidence and will participate education processes without hesitation.

Traditional understanding of education disregards or ignores other qualities of students that are not successful in math courses or verbal courses, and labels these students as unsuccessful or students with learning problems. Theory of Multiple Intelligences defends an understanding of education that underlines finding and developing natural and potential strengths of students. With this understanding, it provides alternative options to develop interests, skills, and talents these individuals possess (Yavuz, 2004).

The most important aspect separating Theory of Multiple Intelligences from traditional approaches is its differing interpretation for the definition of intelligence. According to Gardner (2010), intelligence is the skill to solve problems in real life and to obtain products (Bümen, 2004). In case, the strengths and weaknesses of the intelligence of the students are known and education process is reorganized accordingly, students can be more successful.

\section{Main Problem}

The question, "Is there a significant difference between the success and permanency of learning between groups using Theory of Multiple Intelligences and constructivist approach in teaching 'Resources of Our Country' chapter of the 6th grade Social Sciences course?" is the main question of the study.

\section{Sub Problems}

1. Is there a significant difference between the pretest scores of the experimental group and the control group?

2. Is there a significant difference between the posttest scores of the experimental group and the control group?

3. Is there a significant difference between the permanency of learning scores of the experimental group and the control group?

4. Is there a significant difference between the pretest and posttest scores of the experimental group?

5. Is there a significant difference between the pretest and posttest scores of the control group?

\section{Method}

To test the sup problems of the study pretest-posttest pattern with a control group has been selected as the experimental model. This pattern is used to test the impact of the experimental process on the dependent variable and to provide strong statistical power for the researcher. It is a research pattern that enables evaluation of the findings in a cause and effect relation (Büyüköztürk, 2001).

\section{Study Groups}

This research has been conducted with the 6th grade students of Kuleli Middle School in Bahçelievler County. Class 6/C (36 students) has been selected as the experimental group and class 6/E (33 students) has been selected as the control group. The study employs easily accessible condition sampling because of the study is conducted in the public school where the researcher is employed. With this sampling method, the 
researches selects an easily accessible condition, which earns speed and practicality to the research (Yildırım \& Şimşek, 2011).

\section{Data Gathering}

A test of 20 questions has been developed with respect to the attainments specified in the program of Ministry of National Education (MEB) regarding the chapter of research. "Resources of our Country" along with the opinions of experts. This test has been used for pretest, posttest, and permanency test.

The research conducted in the first semester of the academic year 2014-2015 started in the first week of November and has been completed in the last week of December with application of the final test. A permanency test has been performed four weeks after the last test.

\section{Analysis of the Data}

Descriptive statistical methods have been employed in the evaluation of the data. Since the variables of the research do not fit normal distribution, non-parametric hypothesis test methods have been employed. Man-Whitley $U$ Test has been used to determine the difference between two groups in comparison of quantitative data. Wilcoxon Test has been used to determine the differences between repeated measurements.

\section{Process Steps}

Courses in the control and experimental group have been taught by the researcher. The method of the research is explained as below (see Figure 1):

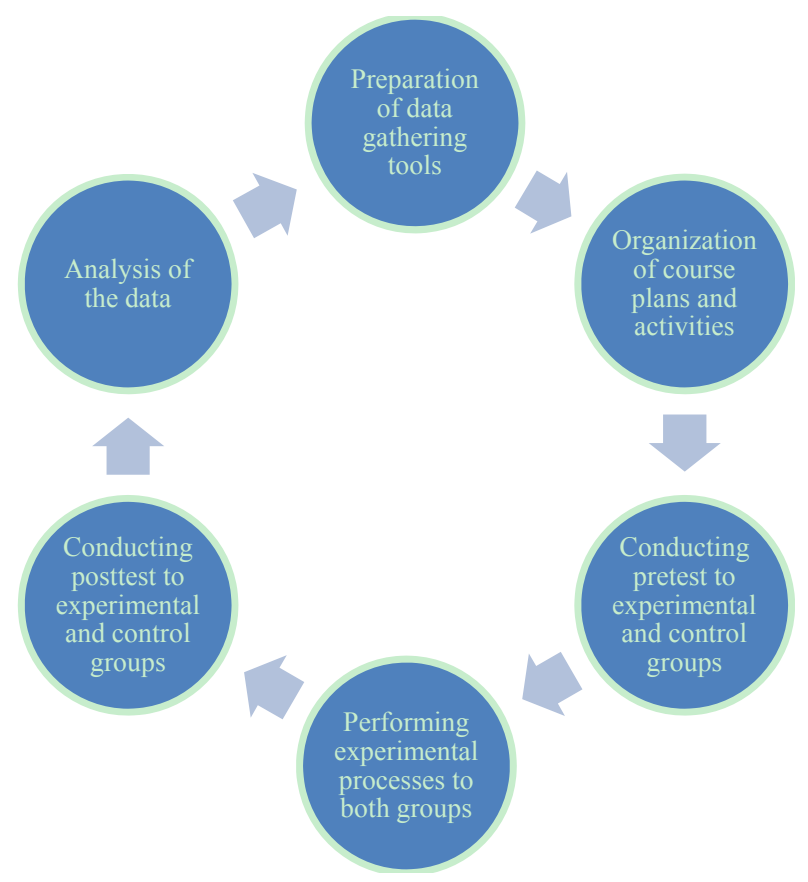

Figure1. The methodology of the research.

\section{Findings and Interpretation}

So, to determine the significance of the difference of the success levels between the experimental group where Theory of Multiple Intelligences have been used and the control group where social sciences education program was used are examined considering the sub problems. 


\section{Comparison of Pretest Results}

As seen in Table 1, the pretest score average of the experimental groups students is 53.05 for "Resources of Our Country" chapter, while the pretest score average of the control group for the same chapter is 50.75 . Mann-Whitney $U$ Test conducted to determine significance of the difference between the pretest results of the groups reveal that group averages are statistically insignificant (Man-Whitney $U=552.500 ; p=0.616>0.05$ ).

Table 1

Distribution of Pretest Success Scores of students by Groups

\begin{tabular}{lllllll}
\hline & Group & $N$ & Avg. & $S D$ & MW & $p$ \\
\hline \multirow{2}{*}{ Success } & Experimental group pretest & 36 & 53.056 & 19.320 & \multirow{2}{*}{552.500} & \multirow{2}{*}{0.616} \\
& Control group pretest & 33 & 50.758 & 17.371 & & \\
\hline
\end{tabular}

\section{Comparison of Posttest Results}

As seen in Table 2, the test average score for the experimental group students is 72.75 , while the posttest average score for the control group is 64.18. Mann-Whitney $U$ Test conducted to determine the significance of the difference between the posttest results of the groups reveal that group averages are statistically significant (Mann-Whitney $U=425.500 ; p=0.042<0.05$ ). By this result, it can be said that education based on Theory of Multiple Intelligences is efficient in achieving relevant goals and attainments.

Table 2

Distribution of Posttest Success Scores of Students by Groups

\begin{tabular}{lllllll}
\hline & Group & $N$ & Avg. & SD & MW & $p$ \\
\hline \multirow{2}{*}{ Success } & Experimental group posttest & 36 & 72.750 & 17.897 & \multirow{2}{*}{425.500} & \multirow{2}{*}{0.042} \\
& Control group posttest & 33 & 64.182 & 12.466 & & \\
\hline
\end{tabular}

\section{Comparison of Permanency Test Averages}

Table 3 reveals that permanency test average is 72.63 for the experimental group students, while the average for the same in the control group is 61.06. Mann-Whitney $U$ Test conducted to determine the significance of the difference between the success score averages of the groups reveal that differences between group averages are statistically significant (Mann-Whitney $U=371.500 ; p=0.007<0.05$ ). With this result, it can be said that Theory of Multiple Intelligences is an efficient method in establishing permanency of the information learned.

Table 3

Distribution of Permanency Success Scores of Students by Groups

\begin{tabular}{lllllll}
\hline & Group & $N$ & Avg. & SD & MW & $p$ \\
\hline \multirow{2}{*}{ Success } & Experimental group permanency & 36 & 72.639 & 19.104 & \multirow{2}{*}{371.500} & \multirow{2}{*}{0.007} \\
& Control group permanency & 33 & 61.061 & 12.168 & & \\
\hline
\end{tabular}

\section{Comparison of the Pretest and Posttest Scores of the Experimental Group}

Table 4 reveals that the pretest and posttest score averages of the experimental group are 53.05 and 72.75 , respectively. Wilcoxon Test performed to reveal whether the difference between the success score averages of students between rpetest and posttest revealed a statistically significant result $(Z=304.000 ; p=0.000<0.05)$.

\section{Comparison of the Pretest and Posttest Scores of the Control Group}

Table 5 reveals that the pretest and posttest score averages of the experimental group are 50.75 and 64.18 , respectively. Mann-Whitney $U$ Test performed to reveal whether the difference between the group averages of 
students between pretest and posttest revealed a statistically significant result (Mann-Whitney $U=299.000 ; p=$ $0.002<0.05)$.

Table 4

Difference Between Experimental Group Pretest and Posttest

\begin{tabular}{|c|c|c|c|c|c|c|}
\hline \multirow{2}{*}{ Groups } & \multicolumn{2}{|c|}{ Experimental group pretest } & \multicolumn{3}{|c|}{ Experimental group posttest } & \multirow{2}{*}{$p$} \\
\hline & Avg. & $S D$ & Avg. & $S D$ & & \\
\hline Success & 53.056 & 19.320 & 72.750 & 17.897 & 304.000 & 0.000 \\
\hline
\end{tabular}

Table 5

Difference Between Control Group Pretest and Posttest

\begin{tabular}{|c|c|c|c|c|c|c|}
\hline \multirow{2}{*}{ Groups } & \multicolumn{2}{|c|}{ Control group pretest } & \multicolumn{2}{|c|}{ Control group posttest } & & \multirow{2}{*}{$p$} \\
\hline & Avg. & $S D$ & Avg. & $S D$ & & \\
\hline Success & 50.758 & 17.371 & 64.182 & 12.466 & 299.000 & 0.002 \\
\hline
\end{tabular}

\section{Conclusions}

According to the results of the pretest conducted in the start of the study to evaluate preparedness of the experimental and the control groups showed that there is no significant difference between the groups. Test score average of the experimental and the control groups are 53.056 and 50.758, respectively. This difference is not statistically significant.

According to the posttest results, the control group students averaged 4.182, while the experimental group averaged 72.750. The difference between the averages of the groups is found statistically significant. This shows that Theory of Multiple Intelligences is an efficient way of learning.

According to the permanency test results conducted after the research, the experimental group scored an average of 72.639, while the control group scored 61.041. The difference between the averages of the groups is found statistically significant. This shows that Theory of Multiple Intelligences is an efficient way in retaining learned topics.

The pretest and posttest results of the experimental group are 53.05 and 72.75 , respectively. The difference between group averages is statistically significant. Education experience arranged, according to the activities of Theory of Multiple Intelligences, can be said to have positive impact on learning.

The pretest and posttest results of the control group are 50.758 and 64.182 , respectively. There is a 13.42 points difference between the retest and posttest. Thus, social sciences education program can establish favorable conditions for students to learn.

In this research, where education process is shaped in two different methods, there is a significant difference between the success of the experimental and control group students in learning "Resources of Our Country" chapter in favor of the experimental group. This success can be said to stem from Theory of Multiple Intelligences, which prevents monotony and respects individual differences.

\section{Recommendations}

The followings are the recommendations for the future research as below:

1. Social sciences textbooks and workbooks should be enriched with visuals, different types of texts to address eight intelligence areas.

2. In cooperation with universities, teacher candidates should have applied training on Theory of Multiple 
Intelligences.

3. Social sciences classrooms with various materials and technologic infrastructure should be provided in schools.

4. Areas addressing different intelligence areas of students should be prepared in schools and classrooms. For example, areas where students can take on responsibilities in animal and plant care to improve their nature intelligence.

5. Classical seating arrangement in public schools is a major hindrance in applying Theory of Multiple Intelligences. In order to efficiently practice Theory of Multiple Intelligences, class size should decrease and seating arrangement should be changed.

(1) Ministry of National Education shall support academic research on the subject;

(2) It should be kept in mind that each student comes to the classroom different dominant intelligence types. Therefore, examinations should be arranged to address difference intelligence areas;

(3) Teachers should avoid praising some intelligence types while ignoring success in others;

(4) This study is based on teaching "Resources of Our Country" chapter of social sciences class based on Theory of Multiple Intelligences. Further studies should choose different chapters of the social sciences class;

(5) This study can be repeated in schools of different socio-economic backgrounds.

\section{References}

Bümen, N. (2001). Applications of multiple intelligences model supported by browsing strategy and its impact on access, attitude and persistency (Ph.D. Thesis on Review, Hacettepe University, Ankara, Turkey).

Büyüköztürk, Ş. (2001). Experimental patterns. Pegem A Publishing: Ankara.

Gardner, H. (2010). Frames of mind: The theory of multiple intelligences. Istanbul: Alfa Yayınlar1.

Kabapınar, Y. (2012). Social sciences instruction: From theory to practice. Ankara: Pegem Academy Publishing

Yavuz, K. E. (2004). Multiple intelligences theory and its applications in education. Ankara: Ceceli Publishing.

Yıldırım, A., \& Şimşek, H. (2011). Qualitative research methods in social sciences. Ankara: Seckin Publishing. 